\title{
Hydrogen Generation from Ammonia-Borane over Ni-B Amorphous Alloys Prepared from Aqueous Solution Based on Thermodynamic Prediction of Hidden Metastable of State
}

\author{
Ai Nozaki*1, Masashi Kuroda*2, Ryota Kameo*2, Hiroshi Ichiwara*2, Ryo Deguchi*2 and \\ Masao Morishita \\ Department of Chemical Engineering and Materials Science Graduate School of Engineering, University of Hyogo, Himeji 671-2201, Japan
}

\begin{abstract}
Amorphous alloys are advantageous to obtain excellent catalytic activity from a disordered atomic arrangement and more dangling bonds. The compositional range of the Ni-B amorphous alloy was thermodynamically predicted. The function of the Gibbs energy of mixing,

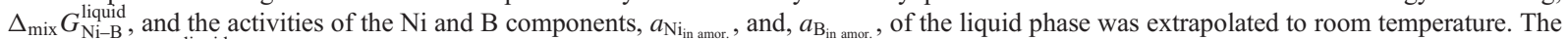
negative $\Delta_{\mathrm{mix}} G_{\mathrm{Ni}-\mathrm{B}}^{\text {liquid }}$ was found from $X_{\mathrm{Ni}}=0.45$ to 0.92 , indicating the existence of the liquid phase as metastable state, i.e. formation of amorphous alloy. The small $a_{\mathrm{Ni}}$ and $a_{\mathrm{B}}$, that is, the strong attractive interaction between the Ni and B components suggested the liquid phase structure was stable. The $\mathrm{Ni}-\mathrm{B}$ amorphous alloys were prepared from aqueous solution using reducing agent consistent well with the thermodynamic prediction. The preparation method from aqueous solution was useful to prevent from thermal migration of the atoms toward the equilibrium state. The quasi equilibrium oxygen pressures, $p_{\mathrm{O}_{2}}\left(\mathrm{Ni}_{\text {in amor. }}\right)$, and, $p_{\mathrm{O}_{2}}\left(\mathrm{~B}_{\text {in amor. }}\right)$, of Ni and $\mathrm{B}$ components in the amorphous alloys were evaluated from $a_{\mathrm{Ni}_{\text {in amor. }}}$ and $a_{\mathrm{B}_{\text {in amor. }}} . p_{\mathrm{O}_{2}}\left(\mathrm{~B}_{\text {in amor. }}\right)$ was found to be smaller than $p_{\mathrm{O}_{2}}\left(\mathrm{Ni}_{\text {in amor. }}\right)$, revealing that $\mathrm{B}$ components in amorphous alloy were preferentially oxidized and inhibited Ni oxidation. Not only a characteristic disordered atomic arrangement but also chemical alloying effect of B results in the excellent catalytic activity of the Ni-B alloy. [doi:10.2320/matertrans.MT-M2020284]
\end{abstract}

(Received September 1, 2020; Accepted June 10, 2021; Published August 25, 2021)

Keywords: nickel boron alloy, amorphous alloy, thermodynamic prediction, catalyst

\section{Introduction}

Amorphous alloys are thermally non-equilibrium materials with a short-range ordered atomic arrangement but no longrange order, and attract attention from academia and industry because of their superior corrosion resistance, mechanical toughness, magnetic, electronic, and catalytic properties compared to crystalline alloys. A. Takeuchi and A. Inoue ${ }^{1,2)}$ proposed the following three empirical rules for the formation of amorphous alloys, which are used as indices for the fabrication of amorphous alloys: (1) The alloy should consist of three or more elements; (2) The respective mixing enthalpies among the constituents should be negative; (3) The atomic size ratio of the constituents should be $12 \%$ or more. ${ }^{1,2)}$ It is possible to predict the constituent elements of amorphous alloys according to these rules obtained from extensive research data. However, it is still difficult to theoretically predict the composition range of amorphous alloys. In determining the composition range of amorphous alloys, the thermodynamic prediction on the basis of the accumulation of experimental data is essential, and no alternative method for the accurate prediction of the composition range of amorphous alloys has been found.

In this study, we focus on the prediction of amorphous alloys compositional ranges based on thermodynamic data. In our previous report, the phase diagram of the $\mathrm{Ni}-\mathrm{W}-\mathrm{B}^{3)}$ and $\mathrm{Ni}-\mathrm{Mo}-\mathrm{B}^{4)}$ ternary systems were determined from the thermodynamic calculation on the basis of the thermodynamic data of the $\mathrm{Ni}-\mathrm{Mo}^{5)}$ and $\mathrm{Ni}-\mathrm{W}^{6}$ solid solutions, $\mathrm{Ni} 3 \mathrm{~B},{ }^{7)} \mathrm{Ni} 2 \mathrm{~B},{ }^{7)} \mathrm{Mo}_{2} \mathrm{~B},{ }^{8)} \mathrm{MoB},{ }^{9)} \mathrm{W}_{2} \mathrm{~B},{ }^{10)} \mathrm{WB},{ }^{10)} \mathrm{NiMo}_{2} \mathrm{~B}_{2},{ }^{5)}$ $\mathrm{NiW}_{2} \mathrm{~B}_{2}{ }^{6}$ and $\mathrm{NiMo}^{5)}$ measured in our laboratory. In this

\footnotetext{
${ }^{* 1}$ Corresponding author, E-mail: nozaki@eng.u-hyogo.ac.jp

${ }^{* 2}$ Graduate Student, University of Hyogo
}

process, the interaction parameter, $\Omega_{\mathrm{Ni}-\mathrm{B}}^{\text {liquid }}$, of the liquid phase in the Ni-B binary system was optimized. ${ }^{3,4,11)}$ Extrapolating the function of the Gibbs energy of mixing, $\left.\Delta_{\text {mix }} G_{\mathrm{N}-\mathrm{B}}^{\text {liquid }}, 3,4,11\right)$ of the liquid phase calculated from $\Omega_{\mathrm{Ni}-\mathrm{B}}^{\text {liquid } 3,411)}$ to room temperature, it is possible to predict the metastable compositional range of the liquid phase structure, i.e., the metastable compositional range of the amorphous structure. In the present study, the compositional range of formation of the $\mathrm{Ni}-\mathrm{B}$ amorphous alloy was predicted from the function of $\Delta_{\text {mix }} G_{\mathrm{N}-\mathrm{B}}^{\text {liquid }}, 3,4,11$ ) and the $\mathrm{Ni}-\mathrm{B}$ amorphous alloy was prepared from aqueous solution using reducing agent. A common method for the preparation of amorphous alloys is the liquid quenching method, which requires the mother alloy to be melted at temperatures above $1000 \mathrm{~K}$ and then rapidly solidified. In this study, Ni-B amorphous alloys were prepared from aqueous solution with minimal temperature variation during the preparation process.

The prepared Ni-B alloy was used as a catalyst in the hydrogen production reaction from ammonia borane. Hydrogen is expected to be a next-generation energy source, but it is difficult to store and transport. As a solution to this problem, hydrogen generation systems using high-hydrogen compounds such as ammonia borane are attracting attention. $\mathrm{Qu}$ et al. ${ }^{12,13)}$ reported that hydrogen was efficiently produced during hydrolysis of ammonia borane $\left(\mathrm{NH}_{3} \mathrm{BH}_{3}+\right.$ $\left.2 \mathrm{H}_{2} \mathrm{O} \rightarrow \mathrm{NH}_{4}^{+}+\mathrm{BO}_{2}^{-}+3 \mathrm{H}_{2}\right)$ in the presence of a metal catalyst. ${ }^{12,13)}$ Therefore, converting hydrogen into ammonia borane once enables safe storage and transportation, and also makes it possible to generate hydrogen as needed. The development of low-cost and highly efficient catalysts is important for the practical application of this system. ${ }^{12,13)}$ We reported that skeletal $\mathrm{Cu},{ }^{14)}$ skeletal $\mathrm{Ni},{ }^{15)} \mathrm{Ru}$-supported $\mathrm{CeO}_{2},{ }^{16)} \mathrm{Ru}-\mathrm{Fe}$-supported $\mathrm{CeO}_{2},{ }^{17)}$ and Ni-supported 
$\mathrm{CeO}_{2}{ }^{18)}$ showed excellent catalytic activity in hydrogen generation reactions from ammonia borane. Among these, $\mathrm{Ni}$ is a relatively inexpensive and highly active metal in hydrogen generation from ammonia borane. In this study, the properties as the catalyst of the $\mathrm{Ni}-\mathrm{B}$ amorphous alloy were also investigated. To investigate the effect of the atomic arrangement on the catalytic properties, $\mathrm{Ni}-\mathrm{B}$ crystalline alloy prepared by heating $\mathrm{Ni}-\mathrm{B}$ amorphous alloy under vacuum. The catalytic properties were evaluated by the hydrogen generation amount from ammonia borane. Moreover, to investigate the effect of B species on the catalytic properties of $\mathrm{Ni}$ species, the quasi equilibrium oxygen pressures, $p_{\mathrm{O}_{2}}\left(\mathrm{Ni}_{\text {in amor. }}\right)$, and, $p_{\mathrm{O}_{2}}\left(\mathrm{~B}_{\text {in amor. }}\right)$, of $\mathrm{Ni}$ and $\mathrm{B}$ components in the amorphous alloys were determined based on the thermodynamic data.

\section{Method}

\subsection{Thermodynamic prediction of formation of amor-} phous alloys

We previously optimized $\Omega_{\mathrm{Ni}-\mathrm{B}}^{\text {liquid }}$ for calculating the $\mathrm{Ni}-$ Mo-B ternary phase diagram, expressed as ${ }^{3,4,11)}$

$$
\begin{aligned}
\Omega_{\mathrm{Ni}-\mathrm{B}}^{\text {liquid }} /\left(\mathrm{J} \cdot \mathrm{mol}^{-1}\right)= & -161870+4.69 \times 10 T \\
& +\left(-327140+1.81 \times 10^{2} T\right)\left(1-2 X_{\mathrm{B}}\right) \\
& +(291380-9.78 \times 10 T)\left(1-2 X_{\mathrm{B}}\right)^{2} \\
& +(85853-5.25 \times 10 T)\left(1-2 X_{\mathrm{B}}\right)^{3} \\
& +(-237160+9.70 \times 10 T)\left(1-2 X_{\mathrm{B}}\right)^{4}
\end{aligned}
$$

where the standard states for $\Omega_{\mathrm{Ni}-\mathrm{B}}^{\text {liquid }}$ are the liquid phases of pure $\mathrm{Ni}$ and pure B. ${ }^{3,4,11)}$

When the pure fcc Ni and rhombohedral $\mathrm{B}$ is taken as the standard states, the function of $\Delta_{\text {mix }} G_{\mathrm{N}-\mathrm{B}}^{\text {liquid }}\left(\mathrm{Ni}^{\mathrm{fcc}}\right.$ and $\left.\mathrm{B}^{\text {rhomb. }}\right)$ was defined as ${ }^{3,4,11)}$

$$
\begin{aligned}
\Delta_{\text {mix }} & G_{\mathrm{N}-\mathrm{B}}^{\text {liquid }}\left(\mathrm{Ni}^{\mathrm{fcc}} \text { and } \mathrm{B}^{\text {rhomb. }}\right) \\
= & \Omega_{\mathrm{Ni}-\mathrm{B}}^{\text {liquid }} X_{\mathrm{Ni}} X_{\mathrm{B}}+\mathrm{R} T\left(X_{\mathrm{Ni}} \ln X_{\mathrm{Ni}}+X_{\mathrm{B}} \ln X_{\mathrm{B}}\right) \\
& +\left({ }^{\circ} G_{\mathrm{Ni}}^{\mathrm{Liquid}}-{ }^{\circ} G_{\mathrm{Ni}}^{\mathrm{fcc}}\right) X_{\mathrm{Ni}}+\left({ }^{\circ} G_{\mathrm{B}}^{\mathrm{Liquid}}-{ }^{\circ} G_{\mathrm{B}}^{\mathrm{rhomb} .}\right) X_{\mathrm{B}}
\end{aligned}
$$

where $\left({ }^{\circ} G_{\mathrm{Ni}}^{\text {Liquid }}-{ }^{\circ} G_{\mathrm{Ni}}^{\mathrm{fcc}}\right)^{19)}$ and $\left({ }^{\circ} G_{\mathrm{B}}^{\text {Liquid }}-{ }^{\circ} G_{\mathrm{B}}^{\text {rhomb. }}\right)^{20)}$ are the standard Gibbs energies of fusion of fcc $\mathrm{Ni}$ and rhombohedral $\mathrm{B}$, given by

$$
\begin{aligned}
& \left({ }^{\circ} G_{\mathrm{Ni}}^{\text {liquid }}-{ }^{\circ} G_{\mathrm{Ni}}^{\mathrm{fcc}}\right) /\left(\mathrm{J} \cdot \mathrm{mol}^{-1}\right)=17615-10.21 T \\
& \left({ }^{\circ} G_{\mathrm{B}}^{\text {liquid }}-{ }^{\circ} G_{\mathrm{B}}^{\mathrm{rhomb}}\right) /\left(\mathrm{J} \cdot \mathrm{mol}^{-1}\right)=50208-21.23 T
\end{aligned}
$$

Extrapolating $\Delta_{\text {mix }} G_{\mathrm{N}-\mathrm{B}}^{\text {liquid }}$ (eq. (2)) to room temperature, the formation composition range of the $\mathrm{Ni}-\mathrm{B}$ amorphous alloy at $298 \mathrm{~K}$ was predicted.

Omori and Hashimoto ${ }^{7)}$ measured the Gibbs energies of mixing of $\mathrm{Ni}_{0.75} \mathrm{~B}_{0.25}$ and $\mathrm{Ni}_{0.67} \mathrm{~B}_{0.33}$, given by

$$
\begin{aligned}
& \Delta_{\text {mix }} G\left(\mathrm{Ni}_{0.75} \mathrm{~B}_{0.25},\left(\mathrm{Ni}^{\text {fcc }} \text { and } \mathrm{B}^{\text {rhomb. }}\right)\right) /\left(\mathrm{J} \cdot \mathrm{mol}^{-1}\right) \\
& =-33201+11.05 T \\
& \Delta_{\text {mix }} G\left(\mathrm{Ni}_{0.67} \mathrm{~B}_{0.33},\left(\mathrm{Ni}^{\text {fcc }} \text { and } \mathrm{B}^{\text {rhomb. }}\right)\right) /\left(\mathrm{J} \cdot \mathrm{mol}^{-1}\right) \\
& =-35733+10.10 T
\end{aligned}
$$

where they ${ }^{7)}$ measured them, taking fcc Ni and rhombohedral $\mathrm{B}$ as the standard states. The phase stability of the amorphous alloys was discussed, compared with these equilibrium phases of $\mathrm{Ni}_{0.75} \mathrm{~B}_{0.25}$ and $\mathrm{Ni}_{0.67} \mathrm{~B}_{0.33}$.
In our previous study, ${ }^{3,4,11)}$ the crystal structure of B was described as orthorhombic. However, strictly speaking, its symmetry is rhombohedral being further lower than orthorhombic. In the present study, the description of crystal structure of B is corrected.

\subsection{Experimental}

\subsubsection{Preparation of the catalyst}

Although the chemical reduction method is the most frequently used for the preparation of metal-boron alloy particles, the intense exothermic reaction between metal ions and boron hydride $\left(\mathrm{BH}_{4}\right)$ induces aggregation of particles and makes it difficult to prepare amorphous alloys stably. ${ }^{21)} \mathrm{S}$. J. Chiang et al. $^{22)}$ succeeded the synthesis of Ni-B amorphous alloys in a water-in-oil microemulsion. However, this system makes it difficult to separate the solvent from the alloy particles and leads to environmental pollution. M. P. Pileni et $a{ }^{23)}$ and M. J. Schwuger et al. ${ }^{24)}$ reported nanoparticle synthesis in reverse microemulsion. Hexing $\mathrm{Li}$ et al. ${ }^{25)}$ reported $\mathrm{Co}-\mathrm{B}$ amorphous alloy by controlling the size of amorphous nanoparticles using the inverse microemulsion method. Following the literature, ${ }^{25)}$ uniform Ni-B amorphous alloys were prepared by chemical reduction of $\mathrm{Ni}^{2+}$ using the oil-in-water microemulsion method. To obtain Ni-B alloys with different atomic ratios, samples with various $\mathrm{NiCl}_{2}$ addition amount ( $i$ mmol, $i=1,2,3,4,5,6,7)$ were prepared. $\mathrm{NiCl}_{2} \cdot 6 \mathrm{H}_{2} \mathrm{O}(\mathrm{immol})$ and polyethylene glycol $(\mathrm{Mw}=$ $20.000,5.0 \mathrm{~g}$ ) were dissolved in distilled water $(40 \mathrm{ml})$. Then $10 \mathrm{~mL}$ of cyclohexane was added to this solution. The mixture was treated under ultrasonic radiation at room temperature for $30 \mathrm{mi}$ to form oil-in-water microemulsion. $10 \mathrm{~mL}$ of $2.0 \mathrm{M} \mathrm{KBH}_{4}$ solution was dropped into the solution with vigorous stirring. After $2 \mathrm{~h}$, the precipitate was washed with distilled water until $\mathrm{pH} 7$ was achieved, then it was washed with ethanol and stored in ethanol until used. The prepared $\mathrm{Ni}-\mathrm{B}$ alloys were denoted as a-Ni-B $(i) \quad(i=$ $1,2,3,4,5,6,7 ; \mathrm{NiCl}_{2}$ addition amount (mmol)). To obtain $\mathrm{Ni}-\mathrm{B}$ particles with the desired composition, an excess amount of B source $\left(\mathrm{KBH}_{4}(\mathrm{aq}), 20 \mathrm{mmol}\right)$ was used. The standard electrochemical potentials, $E^{\circ}$, of elemental $\mathrm{B}(\mathrm{cr})$ from $\mathrm{BH}_{4}^{-}(\mathrm{aq})$ was calculated as -1.185 [V] from the standard Gibbs energy of formation, $\Delta_{\mathrm{f}} G_{\mathrm{m}}^{\circ}$, of $\mathrm{BH}_{4}^{-}(\mathrm{aq})^{26)}$ at 298.15 K (See Appendix). $E^{\circ}$ of elemental $\mathrm{Ni}$ from $\mathrm{Ni}^{2+}$ (aq) was generally known as $-0.237[\mathrm{~V}] .{ }^{27)}$ Therefore, to preparation of the $\mathrm{Ni}-\mathrm{B}$ particle from eutectic precipitation of $\mathrm{BH}_{4}^{-}(\mathrm{aq})$ and $\mathrm{Ni}^{2+}(\mathrm{aq})$, activity of $\mathrm{BH}_{4}^{-}(\mathrm{aq})$ should be increased to compensate such a large precipitation potential difference between -1.185 and -0.237 [V]. Therefore, an excess much amount of $\mathrm{KBH}_{4}$ was used.

As a comparison, a-Ni-B(5) was annealed at $773 \mathrm{~K}$ under vacuum for $2 \mathrm{~h}$ to obtain a $\mathrm{Ni}-\mathrm{B}$ crystalline alloy. Heattreated samples are denoted as c-Ni-B(5).

\subsubsection{Catalyst characterization}

X-ray diffraction (XRD) measurements were performed to analyze the crystallinity of the samples (Ultima IV, Rigaku). In addition, the surface areas of the samples were estimated by the Brunauer-Emmett-Teller method using nitrogen physisorption isotherms obtained at $77 \mathrm{~K}$ (MicrotracBEL Corp. BEL-SORP mini). The X-ray photoelectron spectroscopy (XPS) analyses were conducted employing a 
photoelectron spectrometer (ULVAC-PHI Inc., PHI5000) using monochromatic X-rays ( $\mathrm{Al} \mathrm{K} \alpha, 1486.6 \mathrm{eV})$ to evaluate the atomic ratio. A charge neutralizer (low energy electrons and $\mathrm{Ar}^{+}$ions) was used to compensate for the charging effect. Field emission-scanning electron microscopy (FESEM; JEOL, JSM-7001) was used to determine the surface morphology of the samples.

\subsubsection{Catalytic reaction}

The prepared catalysts $(20 \mathrm{mg})$ were placed in a quartz reaction vessel equipped with a gas burette. An aqueous solution of ammonia borane ( $1 \mathrm{mmol})$ was injected into the vessel to initiate the reaction. The aqueous solution of ammonia borane was stirred magnetically at $308 \mathrm{~K}$ and the progress of the reaction was monitored periodically by reading the scale of the gas burette.

\section{Results and Discussions}

\subsection{Prediction of the composition range of amorphous} alloys

Figure 1 shows the calculated $\Delta_{\text {mix }} G_{\mathrm{N}-\mathrm{B}}^{\text {liquid }}$ at $298.15 \mathrm{~K}$ from eq. (2) as dashed line, compared with the $\Delta_{\text {mix }} G\left(\mathrm{Ni}_{0.75} \mathrm{~B}_{0.25}\right)$ and $\Delta_{\text {mix }} G\left(\mathrm{Ni}_{0.67} \mathrm{~B}_{0.33}\right)$ from eqs. (5) and (6) as solid line. The negative $\Delta_{\text {mix }} G_{\mathrm{N}-\mathrm{B}}^{\text {liquid }}\left(\mathrm{Ni}^{\text {fcc }}\right.$ and $\left.\mathrm{B}^{\text {rhomb. }}\right)$ was found from $X_{\mathrm{Ni}}=0.45$ to 0.92 , indicating that the existence of the liquid phase as metastable state, i.e. formation of amorphous alloy. $\Delta_{\text {mix }} G\left(\mathrm{Ni}_{0.75} \mathrm{~B}_{0.25}\right)$ and $\Delta_{\text {mix }} G\left(\mathrm{Ni}_{0.67} \mathrm{~B}_{0.33}\right)$ of the equilibrium solid phases were found to be more negative than $\Delta_{\text {mix }} G_{\mathrm{N}-\mathrm{B}}^{\text {liquid }}$ of the metastable liquid phase.

Ni-B amorphous alloy particles were prepared from aqueous solution using reducing agent, which allows the alloy synthesis at room temperature. The synthesis at room temperature suppresses the migration of $\mathrm{Ni}$ and $\mathrm{B}$ atoms, preventing them from reaching an equilibrium crystalline state and preserving the amorphous atomic arrangement.

The crystallinity of $\mathrm{Ni}-\mathrm{B}$ alloys prepared from aqueous solution using reducing agent was investigated by XRD

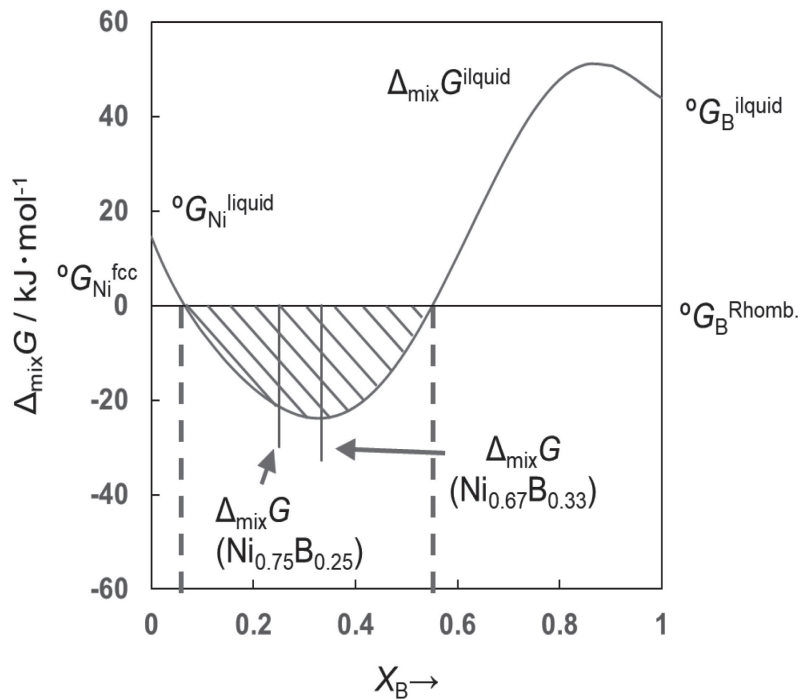

Fig. 1 The extrapolated Gibbs energy of mixing of the liquid phase, $\Delta_{\text {mix }} G,^{3,4,11)}$ of the Ni-B binary system into $298.15 \mathrm{~K}$, compared with those of $\mathrm{Ni}_{0.75} \mathrm{~B}_{0.25}{ }^{7)}$ and $\mathrm{Ni}_{0.67} \mathrm{~B}_{0.33}{ }^{7)}$

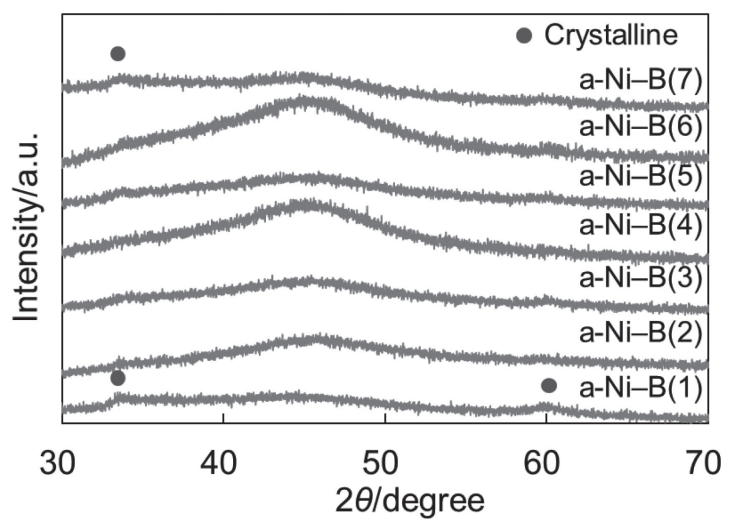

Fig. 2 XRD patterns of a-Ni-B alloys.

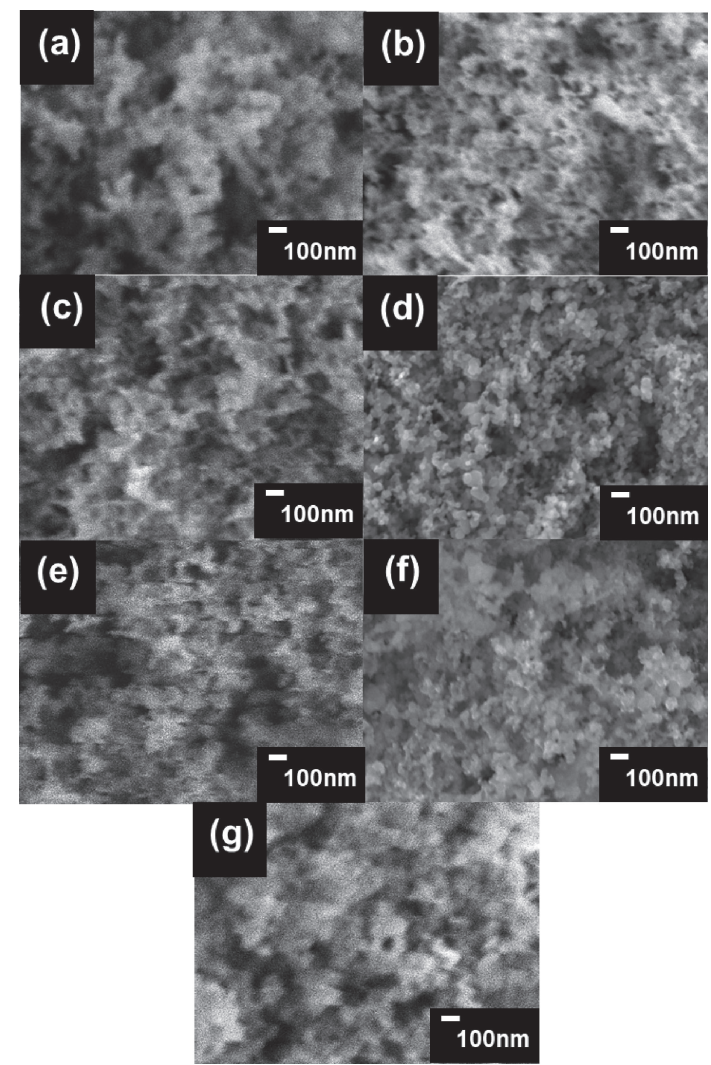

Fig. 3 SEM images of Ni-B amorphous alloy ((a): a-Ni-B(1), (b): a$\mathrm{Ni}-\mathrm{B}(2),(\mathrm{c}): \mathrm{a}-\mathrm{Ni}-\mathrm{B}(3),(\mathrm{d}): \mathrm{a}-\mathrm{Ni}-\mathrm{B}(4)$, (e): a-Ni-B(5), (f): a-Ni-B(6), (g): a-Ni-B(7)).

measurements as shown in Fig. 2. No sharp peaks were observed in a-Ni-B $(2,3,4,5,6)$, but a broad pattern typical of amorphous alloys was observed around $40^{\circ}-55^{\circ}$, suggesting that a-Ni-B(2, 3, 4, 5, 6) were found to be mainly composed of amorphous structure. On the other hand, the peaks in a-Ni-B $(1,7)$ were observed at $33^{\circ}-34^{\circ}$ and $59^{\circ}-61^{\circ}$, suggesting partial crystallization of $\mathrm{Ni}-\mathrm{B}$ alloy.

The surface morphologies of a-Ni-B were observed by SEM. The SEM images of a-Ni-B $(i)(i=1,2,3,4,5,6,7)$ are shown in Fig. 3. Spherical particles were observed in all the samples, and their average diameter was about $40-60 \mathrm{~nm}$.

Table 1 shows the surface areas and atomic ratios of the Ni-B amorphous alloys. The surface area of a-Ni-B(1) was hardly measured by the nitrogen absorption/desorption 
Table 1 Surface area and atomic ratio of Ni-B amorphous alloy.

\begin{tabular}{|c|c|c|c|c|}
\hline \multirow{3}{*}{ Sample } & \multirow{3}{*}{$\begin{array}{c}\text { Surface area } \\
\qquad / \mathrm{m}^{2} \cdot \mathrm{g}^{-1}\end{array}$} & \multirow{2}{*}{\multicolumn{2}{|c|}{$\begin{array}{c}\text { Atomic ratio } \\
\text { /mol\% }\end{array}$}} & \multirow{3}{*}{$\begin{array}{l}\text { XRD results } \\
\text { amorphous } \\
\text { crystalline } \triangle\end{array}$} \\
\hline & & & & \\
\hline & & $\mathrm{Ni}$ & B & \\
\hline $\mathrm{a}-\mathrm{Ni}-\mathrm{B}(1)$ & - & 56 & 44 & $O+\triangle$ \\
\hline $\mathrm{a}-\mathrm{Ni}-\mathrm{B}(2)$ & 53 & 61 & 39 & 0 \\
\hline $\mathrm{a}-\mathrm{N} \mathrm{i}-\mathrm{B}(3)$ & 53 & 65 & 35 & 0 \\
\hline $\mathrm{a}-\mathrm{N} \mathrm{i}-\mathrm{B}(4)$ & 39 & 67 & 33 & $\bigcirc$ \\
\hline $\mathrm{a}-\mathrm{Ni}-\mathrm{B}(5)$ & 66 & 69 & 31 & 0 \\
\hline $\mathrm{a}-\mathrm{Ni}-\mathrm{B}(6)$ & 31 & 71 & 29 & O \\
\hline $\mathrm{a}-\mathrm{Ni}-\mathrm{B}(7)$ & 50 & 74 & 26 & $O+\triangle$ \\
\hline
\end{tabular}

measurement due to the small amount of sample. The surface area of the samples ranged from 30 to $70 \mathrm{~m}^{2} \mathrm{~g}^{-1}$, and a-Ni$\mathrm{B}(5)$ showed the largest surface area among the samples. The atomic ratios of $\mathrm{Ni}$ and $\mathrm{B}$ in the prepared $\mathrm{Ni}-\mathrm{B}$ alloys were investigated by XPS measurements (Table 1). The Ni atomic ratio increased with increasing the amount of $\mathrm{NiCl}_{2}$. Ni-B alloys were prepared in the range of $56-74 \mathrm{~mol} \% \mathrm{Ni}$. Excess much amount of $\mathrm{KBH}_{4}(20 \mathrm{mmol})$ was required to prepare $\mathrm{Ni}-\mathrm{B}$ alloys with high $\mathrm{Ni}$ ratio $(56-74 \mathrm{~mol} \% \mathrm{Ni})$. To prepare $\mathrm{Ni}-\mathrm{B}$ particles from eutectic precipitation of $\mathrm{BH}_{4}^{-}(\mathrm{aq})$ and $\mathrm{Ni}^{2+}(\mathrm{aq})$, it is necessary to increase the activity of $\mathrm{BH}_{4}^{-}(\mathrm{aq})$ to compensate for such a large precipitation potential difference between -1.185 and -0.237 [V] (See Appendix).

The results of XRD measurement (Fig. 2) and XPS measurement (Table 1) showed that the composition range of the amorphous alloy was $61-71 \mathrm{~mol} \% \mathrm{Ni}$. It was found that $\mathrm{Ni}-\mathrm{B}$ amorphous alloys can be formed in a narrower range $(61-71 \mathrm{~mol} \% \mathrm{Ni})$ than in the predicted range (Fig. 1, 45$92 \mathrm{~mol} \% \mathrm{Ni}$ ). There are two reasons that caused the differences between the predicted range $(45-92 \mathrm{~mol} \% \mathrm{Ni})$ and experimental results $(61-71 \mathrm{~mol} \% \mathrm{Ni})$. Firstly, the Ni-B interaction parameters ${ }^{3)}$ determined in our previous study were optimized at high temperatures, and the application of the parameter to room temperature cause discrepancies between the prediction and experimental results. At room temperature, the accumulation of strain energy due to the difference in atomic radii between $\mathrm{Ni}$ and $\mathrm{B}$ atoms cause a positive shift in $\Delta G$, which make the amorphous structure unstable. Secondly, the reaction heat between $\mathrm{KBH}_{4}$ and metal ions affect the thermal activation process to the equilibrium crystal state. When the heat of the reaction is greater than the activation energy to crystallize the amorphous structure, the $\mathrm{Ni}$ and $\mathrm{B}$ atoms migrate toward the equilibrium crystalline state. The thermodynamic equilibrium theory hardly deals with the kinetic process of crystallization of amorphous structures.

\subsection{Hydrogen generation over $\mathrm{Ni}-\mathrm{B}$ amorphous alloys}

To investigate the effect of the composition ratio of $\mathrm{Ni}-\mathrm{B}$ alloys on the catalytic activity, the hydrogen generation from ammonia borane was carried out over a-Ni-B $(i) \quad(i=$ $1,2,3,4,5,6,7)$. Figure 4 showed the hydrogen generation amount per surface area over a-Ni-B $(i)(i=1,2,3,4,5,6,7)$

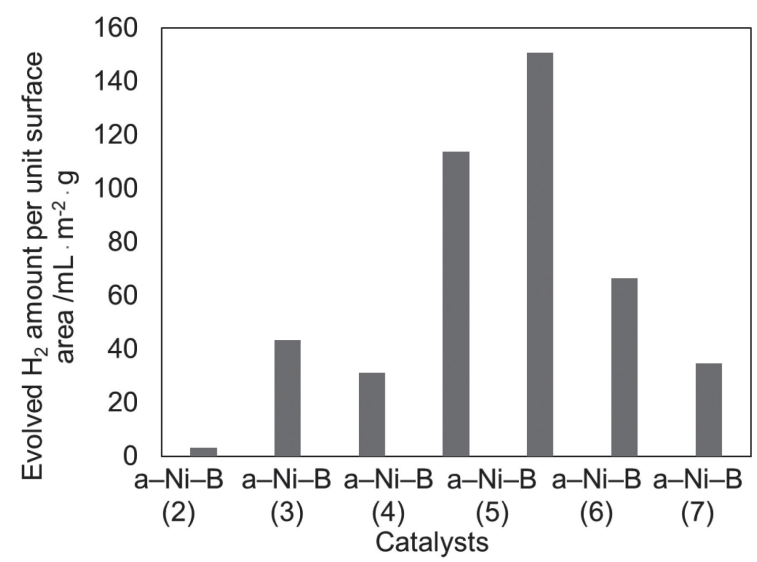

Fig. 4 Amount of evolved hydrogen per sample surface area over prepared $\mathrm{Ni}-\mathrm{B}$ alloy.

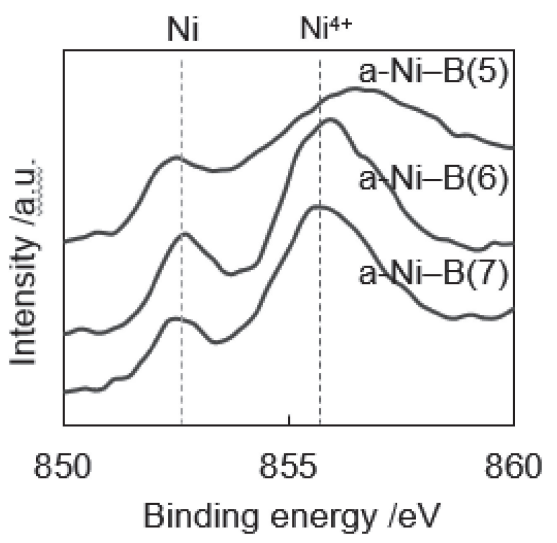

Fig. 5 Ni2p XPS spectra of Ni-B alloys.

at $10 \mathrm{~min}$. a-Ni-B(5) showed the highest catalytic activity per surface area (Table 1), despite its higher surface area than the other samples. The catalytic activity increased with the increase in the amount of $\mathrm{Ni}$, suggesting that $\mathrm{Ni}$ is the active site in this reaction. However, the activity of a-Ni-B(6) and a-Ni-B(7) decreased with increasing $\mathrm{Ni}$ ratio.

The oxidation state of $\mathrm{Ni}$ was measured by XPS to investigate the reason for the decrease in the catalytic activity of a-Ni-B(6) and a-Ni-B(7). Figure 5 and Table 2 shows the Ni2p3/2 XPS spectra and the area ratios of $\mathrm{Ni}$ and $\mathrm{Ni}^{2+}$, respectively. Table 2 also shows the area ratios of $\mathrm{Ni}$ and $\mathrm{Ni}^{2+}$ for the $\mathrm{Ni}$ supported porous $\mathrm{CeO}_{2}$, as reported previously. ${ }^{18)}$ The Ni particles without B species were easily oxidized by exposure to air and showed no catalytic activity. ${ }^{18)}$ The XPS area ratio of $\mathrm{Ni}^{2+}$ increased with the decrease in $\mathrm{B}$ content. The decrease in the catalytic activity of a-Ni-B(6) and a-Ni-B(7) was attributed to a decrease in the ratio of $\mathrm{Ni}^{0}$ as the $\mathrm{B}$ content decreased. Ellingham diagram determined by $\mathrm{B}$. Thomas ${ }^{28)}$ showed that $\mathrm{B}$ species were more easily oxidized than $\mathrm{Ni}$ species, suggesting that the oxidation of $\mathrm{Ni}$ species was suppressed by the preferential oxidation of $\mathrm{B}$. We subsequently evaluated the quasi equilibrium oxygen pressures, $p_{\mathrm{O}_{2}}\left(\mathrm{Ni}_{\text {in amor. }}\right)$, and, $p_{\mathrm{O}_{2}}\left(\mathrm{~B}_{\text {in amor. }}\right)$, of $\mathrm{Ni}$ and $\mathrm{B}$ components in the amorphous alloys to confirm the oxidation state of Ni-B amorphous alloy. The relative partial molar Gibbs energies of the $\mathrm{Ni}$ and $\mathrm{B}$ components in amorphous alloys, $\Delta \bar{G}_{\mathrm{Ni}}^{\text {liquid }}$ and $\Delta \bar{G}_{\mathrm{B}}^{\text {liquid }}$, are defined as 
Table 2 XPS area ratio $\left(\mathrm{Ni}^{0}\right.$ and $\left.\mathrm{Ni}^{2+}\right)$.

\begin{tabular}{ccc}
\hline & XPS area $\mathrm{ratio}$ \\
$\mathrm{S}$ a m le & $\mathrm{Ni}^{0}$ & $\mathrm{Ni}^{2+}$ \\
\hline $\mathrm{a}-\mathrm{Ni}-\mathrm{B}(5)$ & 44 & 56 \\
$\mathrm{a}-\mathrm{Ni}-\mathrm{B}(6)$ & 18 & 82 \\
$\mathrm{a}-\mathrm{Ni}-\mathrm{B}(7)$ & 12 & 91
\end{tabular}

$$
\begin{aligned}
\Delta \bar{G}_{\mathrm{Ni}}^{\text {liquid }}= & \Delta_{\text {mix }} G^{\text {liquid }}-X_{\mathrm{B}}^{\text {liquid }} \frac{\partial \Delta_{\text {mix }} G^{\text {liquid }}}{\partial X_{\mathrm{B}}^{\text {liquid }}} \\
= & \mathrm{R} T \ln \left(1-X_{\mathrm{B}}^{\text {liquid }}\right) \\
& +\left(\Omega_{\mathrm{Ni}-\mathrm{B}}^{\text {liquid }}-\left(1-X_{\mathrm{B}}^{\text {liquid }}\right) \frac{\partial \Omega_{\mathrm{Ni}-\mathrm{B}}^{\text {liquid }}}{\partial X_{\mathrm{B}}^{\text {liquid }}}\right)\left(X_{\mathrm{B}}^{\text {liquid }}\right)^{2} \\
& +\left({ }^{\circ} G_{\mathrm{Ni}}^{\text {liquid }}-{ }^{\circ} G_{\mathrm{Ni}}^{\text {fcc }}\right) \\
\Delta \bar{G}_{\mathrm{B}}^{\text {liquid }}= & \Delta_{\text {mix }} G^{\text {liquid }}+\left(1-X_{\mathrm{B}}^{\text {liquid }}\right) \frac{\partial \Delta_{\text {mix }} G^{\text {liquid }}}{\partial X_{\mathrm{B}}^{\text {liquid }}} \\
= & \mathrm{R} T \ln X_{\mathrm{B}}^{\text {liquid }} \\
& +\left(\Omega_{\mathrm{Ni}-\mathrm{B}}^{\text {liquid }}+X_{\mathrm{B}}^{\text {liquid }} \frac{\partial \Omega_{\mathrm{Ni}}^{\text {liqu }}}{\partial X_{\mathrm{B}}^{\text {liquid }}}\right)\left(1-X_{\mathrm{B}}^{\text {liquid }}\right)^{2} \\
& +\left({ }^{\circ} G_{\mathrm{B}}^{\text {liquid }}-{ }^{\circ} G_{\mathrm{B}}^{\text {rhomb. }}\right)
\end{aligned}
$$

The activities of $\mathrm{Ni}$ and $\mathrm{B}$ components in the amorphous alloys, $a_{\mathrm{Ni}_{\text {in amor. }}}$ and $a_{\mathrm{B}_{\text {in amor. }}}$, are given by eqs. (9) and (10).

$$
\begin{aligned}
& a_{\mathrm{Ni}_{\text {in amor. }}}=\exp \left(\frac{\Delta \bar{G}_{\mathrm{Ni}}^{\text {liquid }}}{\mathrm{R} T}\right) \\
& a_{\mathrm{B}_{\text {in amor. }}}=\exp \left(\frac{\Delta \bar{G}_{\mathrm{B}}^{\text {liquid }}}{\mathrm{R} T}\right)
\end{aligned}
$$

The oxidation reactions of the nickel and boron components in the amorphous alloys, $\mathrm{Ni}_{\text {in amor., }}$ and, $\mathrm{B}_{\text {in amor., }}$, to form $\mathrm{NiO}$ and $\mathrm{B}_{2} \mathrm{O}_{3}$ are expressed as eq. (11) and (12), respectively

$$
\begin{aligned}
& 2 \mathrm{Ni}_{\text {in amor. }}+\mathrm{O}_{2}=2 \mathrm{NiO} \\
& 4 / 3 \mathrm{~B}_{\text {in amor. }}+\mathrm{O}_{2}=2 / 3 \mathrm{~B}_{2} \mathrm{O}_{3}
\end{aligned}
$$

where $\Delta_{\mathrm{r}} G^{\circ}$ is expressed as eq. (13) and (14), and $K$ is the equilibrium constant namely

$$
\begin{aligned}
\Delta_{\mathrm{r}} G^{\circ} & =-\mathrm{R} T \ln K \\
& =-\mathrm{R} T \ln \frac{a_{\mathrm{NiO}^{2}}^{2}}{a_{\mathrm{Ni}_{\text {in amor. }}^{2}}^{2}\left(\frac{p_{\mathrm{O}_{2}}}{p^{\circ}}\right)} \\
& =\mathrm{R} T \ln a_{\mathrm{Ni}_{\text {in amor. }}}^{2}+\mathrm{R} T \ln \left(\frac{p_{\mathrm{O}_{2}}}{p^{\circ}}\right) \\
& =2 \Delta_{\mathrm{f}} G^{\circ}(\mathrm{NiO})
\end{aligned}
$$

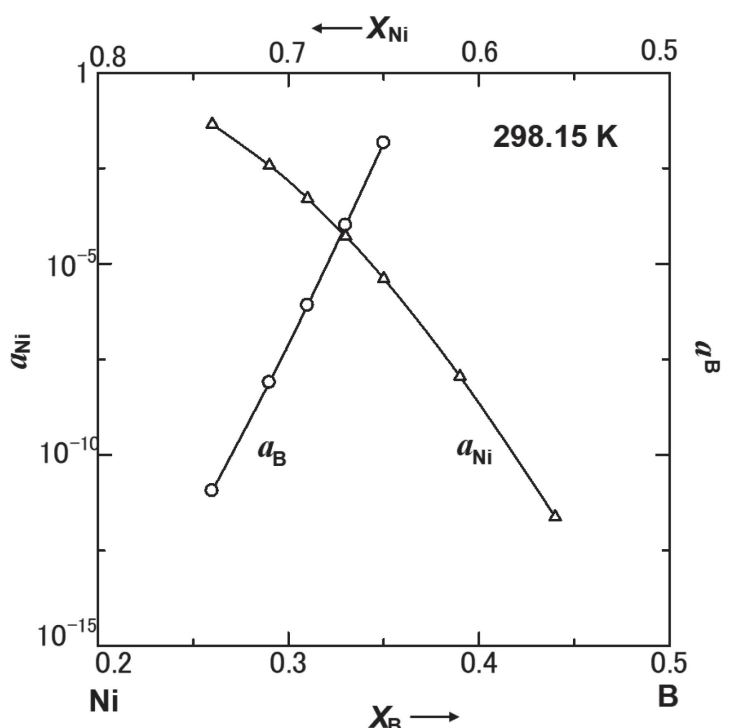

Fig. 6 Activities of $\mathrm{Ni}$ and $\mathrm{B}$ components in the amorphous alloys, $a_{\mathrm{Ni}_{\text {in amor }}}$ and $a_{\mathrm{B}_{\text {in amor. }}}$, at $298.15 \mathrm{~K}$.

$$
\begin{aligned}
\Delta_{\mathrm{r}} G^{\circ} & =-\mathrm{R} T \ln K \\
& =-\mathrm{R} T \ln \frac{a_{\mathrm{B}_{2} \mathrm{O}_{3}}^{\frac{2}{3}}}{a_{\mathrm{B}_{\text {in amor. }}^{\frac{4}{3}}}\left(\frac{p_{\mathrm{O}_{2}}}{p^{\circ}}\right)} \\
& =\mathrm{R} T \ln a_{\mathrm{B}_{\text {in amor. }}^{\frac{4}{3}}}+\mathrm{R} T \ln \left(\frac{p_{\mathrm{O}_{2}}}{p^{\circ}}\right) \\
& =2 / 3 \Delta_{\mathrm{f}} G^{\circ}\left(\mathrm{B}_{2} \mathrm{O}_{3}\right)
\end{aligned}
$$

The quasi equilibrium oxygen pressures, $p_{\mathrm{O}_{2}}\left(\mathrm{Ni}_{\text {in amor. }}\right)$, and, $p_{\mathrm{O}_{2}}\left(\mathrm{~B}_{\text {in amor. }}\right)$, of $\mathrm{Ni}$ and $\mathrm{B}$ components in the amorphous alloys are expressed as eq. (15) and (16),

$$
\begin{aligned}
& \frac{p_{\mathrm{O}_{2}}}{p^{\circ}}=\exp \left\{-\ln a_{\mathrm{Ni}_{\text {in amor. }}}^{2}+(2 / \mathrm{R} T) \Delta_{\mathrm{f}} G^{\circ}(\mathrm{NiO})\right\} \\
& \frac{p_{\mathrm{O}_{2}}}{p^{\circ}}=\exp \left\{-\ln a_{\mathrm{B}_{\text {in amor. }}^{\frac{4}{3}}}+(2 / 3 \mathrm{R} T) \Delta_{\mathrm{f}} G^{\circ}\left(\mathrm{B}_{2} \mathrm{O}_{3}\right)\right\}
\end{aligned}
$$

where $\Delta_{\mathrm{f}} G^{\circ}$ values for $\mathrm{NiO}$ and $\mathrm{B}_{2} \mathrm{O}_{3}$ were referenced from relevant data for $\mathrm{NiO}(=-211.660[\mathrm{~kJ}$ (mol of compound $\left.\left.{ }^{-1}\right)^{26}\right) ; \quad \mathrm{B}_{2} \mathrm{O}_{3}, \quad(=-1194.324 \quad[\mathrm{~kJ} \quad(\mathrm{~mol}$ of compound $\left.\left.{ }^{-1}\right)^{26)}\right]$ ).

Figure 6 shows $a_{\mathrm{Ni}_{\text {in amor. }}}$ and $a_{\mathrm{B}_{\text {in amor. }}} \cdot a_{\mathrm{B}_{\text {in amor. }}}$ was found to be increased with increasing $X_{\mathrm{B}}^{\text {liquid }}$, while $a_{\mathrm{Ni}_{\text {in amor. }} \text {. was found }}$ to be decreased with increasing $X_{\mathrm{B}}^{\text {liquid }}$ following the GibbsDuhem relationship. The obtained small $a_{\mathrm{Ni}_{\text {in amor. }}}$ and $a_{\mathrm{B}_{\text {in amor. }}}$ means that the attractive interaction act between the $\mathrm{Ni}$ and $\mathrm{B}$ atoms. The amorphous structure is concluded to be resulted from the attractive interaction.

Figure 7 shows $p_{\mathrm{O}_{2}}\left(\mathrm{Ni}_{\text {in amor. }}\right)$ and $p_{\mathrm{O}_{2}}\left(\mathrm{~B}_{\text {in amor. }}\right)$. The $p_{\mathrm{O}_{2}}\left(\mathrm{~B}_{\text {in amor. }}\right)$ data were found to be smaller than $p_{\mathrm{O}_{2}}\left(\mathrm{Ni}_{\text {in amor. }}\right)$, indicating that the component of $\mathrm{B}$ was preferentially oxidized, that is, the component of $\mathrm{B}$ prevented the component of $\mathrm{Ni}$ from oxidation. This is reason for the excellent catalytic activity of the obtained amorphous alloys.

Table 3 summarized the relative partial molar Gibbs

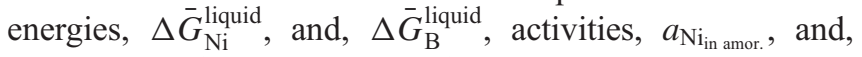
$a_{\mathrm{B}_{\text {in amor. }}}$ and quasi equilibrium oxygen pressures, $p_{\mathrm{O}_{2}}\left(\mathrm{Ni}_{\text {in amor. }}\right)$, and, $p_{\mathrm{O}_{2}}\left(\mathrm{~B}_{\text {in amor. }}\right)$, of $\mathrm{Ni}$ and $\mathrm{B}$ components in the amorphous alloys. $\Delta \bar{G}_{\mathrm{B}}^{\text {liquid }}$ of a-Ni-B(1) and a-Ni- 


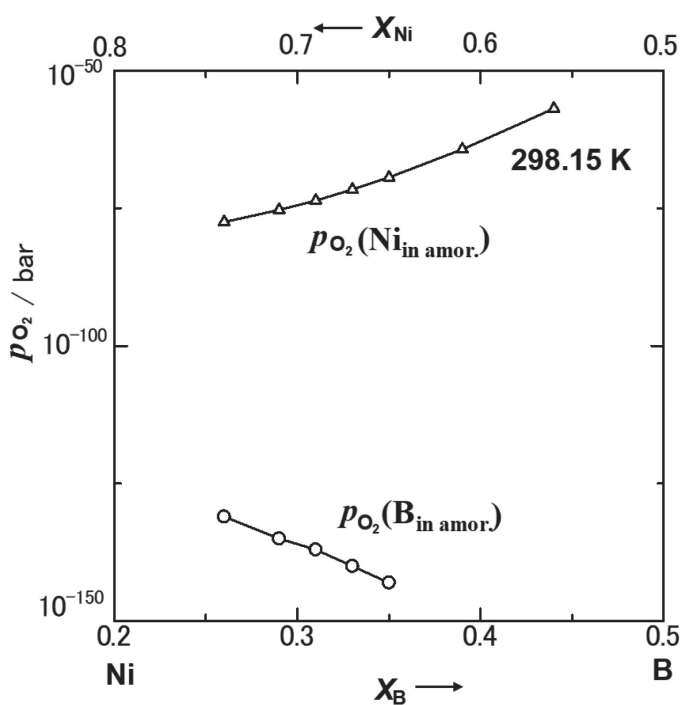

Fig. 7 Quasi equilibrium oxygen pressures, $p_{\mathrm{O}_{2}}\left(\mathrm{Ni}_{\text {in amor. }}\right)$, and, $p_{\mathrm{O}_{2}}\left(\mathrm{~B}_{\mathrm{in}}\right.$ amor. $)$, of $\mathrm{Ni}$ and $\mathrm{B}$ components in the amorphous alloys.

$\mathrm{B}(2)$ were positive, indicating $\mathrm{B}$ is difficult to dissolve into the liquid-like structure. $\mathrm{As}$ a result, $\mathrm{Ni}_{2} \mathrm{~B}$ crystals were precipitated in a-Ni-B(1) consistent with its positive value of $\Delta \bar{G}_{\mathrm{B}}^{\text {liquid }}$. However, no crystalline precipitates were observed in a-Ni-B $(2)$ despite the positive value of $\Delta \bar{G}_{\mathrm{B}}^{\text {liquid }}$. It is likely that the negative value of $\Delta \bar{G}_{\mathrm{Ni}}^{\text {liquid }}$ had a large stabilizing effect on the amorphous structure, resulting in a negative $\Delta_{\text {mix }} G$, and thus, no crystalline precipitates were formed in a-Ni-B(2). On the other hand, $\mathrm{Ni}_{2} \mathrm{~B}$ crystals were formed despite the negative value of $\Delta \bar{G}_{\mathrm{Ni}}^{\text {liquid }}$, and, $\Delta \bar{G}_{\mathrm{B}}^{\text {liquid }}$ of a-Ni$\mathrm{B}(7)$. The present reaction to form the amorphous alloys were exothermic. The heat during synthesis in a-Ni-B(7) accelerated to reach the equilibrium state, resulting in precipitation of $\mathrm{Ni}_{2} \mathrm{~B}$.

$\mathrm{Ni}-\mathrm{B}$ crystalline alloy $(\mathrm{c}-\mathrm{Ni}-\mathrm{B}(5))$ was prepared by heated a-Ni-B(5) to compare the catalytic properties of amorphous and crystalline alloys. $\mathrm{N}_{2}$ adsorption and desorption measurements were performed and found that the surface area of $\mathrm{c}-\mathrm{Ni}-\mathrm{B}(5)\left(3 \mathrm{~m}^{2} \mathrm{~g}^{-1}\right)$ was much smaller than that of a-Ni-B(5) $\left(66 \mathrm{~m}^{2} \mathrm{~g}^{-1}\right)$, indicating that the particles were agglomerated by the heat treatment. Figure 8 shows the hydrogen production at $10 \mathrm{~min}$ per unit surface area of a-Ni-B(5) and $\mathrm{c}-\mathrm{Ni}-\mathrm{B}(5)$. The catalytic activity per surface area of a-Ni$\mathrm{B}(5)$ was found to be higher than that of the c-Ni-B(5), suggesting that the amorphous structure was effective in improving the catalytic activity. Amorphous alloys have a disordered atomic arrangement and more dangling bonds than crystalline alloys. It is assumed that the dangling bonds positively effect on the catalytic activity. The preparation of crystalline transition metal borides requires high temperatures and energy. The crystalline transition metal borides are generally prepared by sintering transition metal and boron powders at temperatures above $1400 \mathrm{~K}{ }^{29)} \mathrm{Ni}-\mathrm{B}$ amorphous

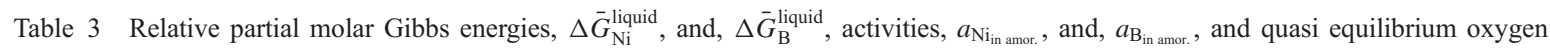
pressures, $p_{\mathrm{O}_{2}}\left(\mathrm{Ni}_{\text {in amor. }}\right)$, and, $p_{\mathrm{O}_{2}}\left(\mathrm{~B}_{\text {in amor. }}\right)$, of $\mathrm{Ni}$ and $\mathrm{B}$ components in the amorphous alloys. $\mathrm{E} \pm k l$ indicates the power of 10 .

\begin{tabular}{|c|c|c|c|c|c|c|c|c|c|}
\hline \multirow[t]{2}{*}{$\begin{array}{c}\text { S a m p } 1 \\
\text { e }\end{array}$} & \multicolumn{2}{|c|}{$\begin{array}{c}\text { A tom ic } \\
\text { ratio } \\
/ \%\end{array}$} & \multirow{2}{*}{$\begin{array}{c}\Delta \bar{G}_{\mathrm{Ni}}^{\mathrm{L}} \\
\mathrm{k} \mathrm{J} \\
\mathrm{mo} 1^{-1}\end{array}$} & \multirow{2}{*}{$\begin{array}{c}\Delta \bar{G}_{\mathrm{B}}^{\mathrm{L}} \\
\mathrm{k} \mathrm{J} \\
\mathrm{mol} \mathrm{l}^{-1}\end{array}$} & \multirow[t]{2}{*}{$a_{\mathrm{Ni}_{\text {in }} \text { amor. }}$} & \multirow[t]{2}{*}{$a_{\mathrm{B}_{\text {in amor. }}}$} & \multirow{2}{*}{$\begin{array}{c}p_{\mathrm{O}_{2}} \\
\left(\mathrm{Ni}_{\text {in amor. }}\right. \\
\text { b a r }\end{array}$} & \multirow{2}{*}{$\begin{array}{c}p_{\mathrm{O}_{2}} \\
\left(\mathrm{~B}_{\text {in amor. }}\right) \\
\text { b a r }\end{array}$} & \multirow{2}{*}{$\begin{array}{l}\text { Struct } \\
\text { ure }\end{array}$} \\
\hline & $\mathrm{Ni}$ & $\mathrm{B}$ & & & & & & & \\
\hline $\mathrm{a}-\mathrm{Ni}-$ & 56 & 44 & -66.34 & 43.97 & 2.387 & - & 1.208 & - & a mor. \\
\hline $\mathrm{B}(1)$ & & & & & $\mathrm{E}-12$ & & $E-57$ & & $+\mathrm{Ni}_{2} \mathrm{~B}$ \\
\hline $\mathrm{a}-\mathrm{Ni}-$ & 61 & 39 & -45.35 & 14.39 & 1.133 & - & 5.363 & - & a mor. \\
\hline$B(2)$ & & & & & $E-08$ & & $E-65$ & & \\
\hline $\mathrm{a}-\mathrm{N} \mathrm{i}-$ & 65 & 35 & -30.75 & -10.47 & 4.106 & 1.467 & 4.083 & 9.003 & a mor. \\
\hline B ( 3 ) & & & & & E- 06 & E- 02 & $\mathrm{E}-70$ & E- 144 & \\
\hline $\mathrm{a}-\mathrm{N} \mathrm{i}-$ & 67 & 33 & -24.41 & -22.76 & 5.290 & 1.029 & 2.461 & 6.703 & a mor. \\
\hline$B(4)$ & & & & & $E-05$ & E- 04 & $\mathrm{E}-72$ & $\mathrm{E}-141$ & \\
\hline $\mathrm{a}-\mathrm{Ni}-$ & 69 & 31 & -18.77 & -34.74 & 5.144 & 8.210 & 2.602 & 4.206 & a mor. \\
\hline B ( 5 ) & & & & & E- 04 & E- 07 & E - 74 & $E-138$ & \\
\hline $\mathrm{a}-\mathrm{N} \mathrm{i}-$ & 71 & 29 & -13.83 & -46.25 & 3.771 & 7.885 & 4.842 & 2.060 & a mor. \\
\hline $\mathrm{B}(6)$ & & & & & $E-03$ & E-09 & E - 76 & $E-135$ & \\
\hline $\mathrm{a}-\mathrm{N} \mathrm{i}-$ & 74 & 26 & -7.68 & -62.45 & 4.510 & 1.148 & 3.388 & 1.248 & a mor. \\
\hline B ( 7 ) & & & & & E- 02 & $\mathrm{E}-11$ & $\mathrm{E}-78$ & $\mathrm{E}-131$ & + \\
\hline & & & & & & & & & $\mathrm{Ni}_{2} \mathrm{~B}$ \\
\hline
\end{tabular}




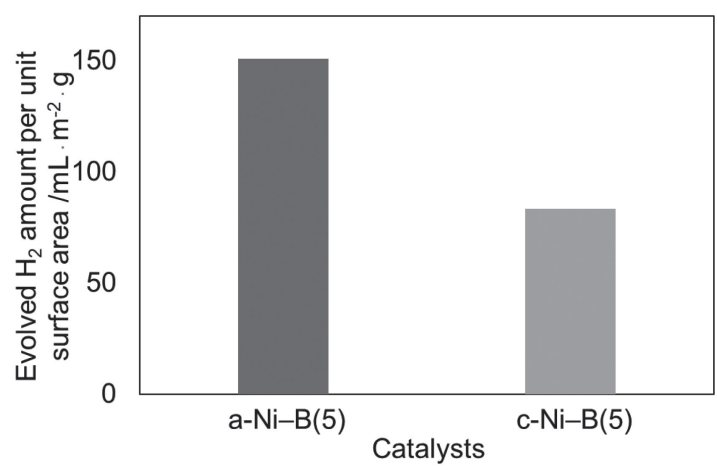

Fig. 8 Amount of evolved hydrogen per surface area.

alloys, which exhibited high catalytic activity, were excellent materials that were prepared from aqueous solutions at low temperatures.

\section{Conclusion}

The compositional range of the Ni-B amorphous alloy was thermodynamically predicted from extrapolating the function of the Gibbs energy of mixing, $\Delta_{\text {mix }} G_{\mathrm{N}-\mathrm{B}}^{\text {liquid }}$, and the activities

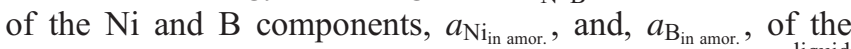
liquid phase to room temperature. The negative $\Delta_{\text {mix }} G_{\mathrm{N}-\mathrm{B}}^{\text {liquid }}$ was found to be from $X_{\mathrm{Ni}}=0.45$ to 0.92 , indicating the existence of the liquid phase as metastable state, i.e. formation of amorphous alloy. $a_{\mathrm{Ni}_{\text {in amor. }}}$ and $a_{\mathrm{B}_{\text {in amor. }}}$ showed that the strong attractive interaction acted between the $\mathrm{Ni}$ and B components. The Ni-B amorphous alloys were prepared from aqueous solution using reducing agent from $X_{\mathrm{Ni}}=0.61$ to 0.71 , following the quasi equilibrium thermodynamic prediction. The Ni-B amorphous alloy showed excellent catalytic properties in the hydrogen generation reaction from ammonia borane. Moreover, the quasi equilibrium oxygen pressures, $p_{\mathrm{O}_{2}}\left(\mathrm{Ni}_{\text {in amor. }}\right)$, and, $p_{\mathrm{O}_{2}}\left(\mathrm{~B}_{\text {in amor. }}\right)$, of $\mathrm{Ni}$ and $\mathrm{B}$ components in the amorphous alloys were evaluated from $a_{\mathrm{Ni}_{\text {in amor. }}}$ and $a_{\mathrm{B}_{\text {in amor. }}} . p_{\mathrm{O}_{2}}\left(\mathrm{~B}_{\text {in amor. }}\right)$ was found to be smaller than $p_{\mathrm{O}_{2}}\left(\mathrm{Ni}_{\text {in amor. }}\right)$, revealing that $\mathrm{B}$ components in amorphous alloy were preferentially oxidized and inhibited $\mathrm{Ni}$ oxidation. Not only disordered atomic arrangement but also inhibition of oxidation of the Ni components are reasons for the excellent catalytic activity of the $\mathrm{Ni}-\mathrm{B}$ amorphous alloy.

\section{Acknowledgments}

This study was partially supported by a Grant from university of Hyogo and a Grant-in-Aid for Young Scientists (No. 20K15051) from the Ministry of Education, Culture, Sports, Science and Technology (MEXT), Japan.

\section{Appendix}

In our previous studies, ${ }^{30,31)}$ the standard electrochemical potential, $E^{\circ}$, of molybdic acid aqueous ion $\left(\mathrm{MoO}_{4}{ }^{2-}(\mathrm{aq})\right)$ from the elements was determined from a thermodynamic cycle composed of the related substances as one of the NEA OECD nuclear waste management. ${ }^{32)}$ Presently, $E^{\circ}$ of precipitation of elemental $\mathrm{B}(\mathrm{cr})$ from $\mathrm{BH}_{4}^{-}(\mathrm{aq})$ was calculated. $\Delta_{\mathrm{f}} G_{\mathrm{m}}^{\circ}$ of $\mathrm{BH}_{4}^{-}(\mathrm{aq})$ at $298.15 \mathrm{~K}$ was given by eq. (A1).

$$
\begin{aligned}
& \mathrm{B}(\mathrm{cr})+2 \mathrm{H}_{2}(\mathrm{~g})+\mathrm{e}^{-}=\mathrm{BH}_{4}^{-}(\mathrm{aq}) \\
& \Delta_{\mathrm{f}} G_{\mathrm{m}}^{\circ}\left(\mathrm{BH}_{4}^{-}(\mathrm{aq})\right)=114.35\left[\mathrm{~kJ}(\mathrm{~mol} \text { of compd. })^{-1}\right]^{33)}
\end{aligned}
$$

Hydrogen reaction is defined as

$$
\begin{aligned}
& \mathrm{H}_{2}(\mathrm{~g})=2 \mathrm{H}^{+}(\mathrm{aq})+2 \mathrm{e}^{-} \\
& \Delta_{\mathrm{r}} G^{\circ}(\mathrm{A} 2)=0[\mathrm{~kJ}]
\end{aligned}
$$

The standard Gibbs energy of reaction of precipitation of $\mathrm{B}(\mathrm{cr})$ from $\mathrm{BH}_{4}^{-}(\mathrm{aq})$ was defined as eq. (A3).

$$
\begin{aligned}
& \mathrm{BH}_{4}^{-}(\mathrm{aq})+\mathrm{H}^{+}(\mathrm{aq})=\mathrm{B}(\mathrm{cr})+\frac{5}{2} \mathrm{H}_{2}(\mathrm{~g}) \\
& \Delta_{\mathrm{r}} G^{\circ}(\mathrm{A} 3)=-114.35[\mathrm{~kJ}]
\end{aligned}
$$

Namely, $E^{\circ}$ of precipitation of elemental $\mathrm{B}(\mathrm{cr})$ from $\mathrm{BH}_{4}^{-}$(aq) was given by eq. (A4)

$$
E^{\circ}=-\frac{\Delta_{\mathrm{r}} G^{\circ}(\mathrm{A} 3)}{-\mathrm{F}}=-1.185[\mathrm{~V}]
$$

where $\mathrm{F}$ is Faraday constant $\left(9.6485 \times 10^{4}\left[\mathrm{C} \mathrm{mol}^{-1}\right]\right)$. $\mathrm{C}$ is Coulomb, that is, $1[\mathrm{~J}]=1[\mathrm{CV}]$.

\section{REFERENCES}

1) A. Takeuchi and A. Inoue: Mater. Trans., JIM 41 (2000) 1372-1378.

2) A. Takeuchi and A. Inoue: Mater. Trans. 46 (2005) 2817-2829.

3) M. Morishita, K. Koyama, K. Maeda and G. Zhang: Mater. Trans. JIM 40 (1999) 600-605.

4) M. Morishita, K. Koyama, S. Yagi and G. Zhang: J. Alloy. Compd. 314 (2001) 212-218.

5) K. Koyama, Y. Hashimoto, K. Suzuki and H. Matsuo: J. Japan Inst. Metals 53 (1989) 183-188.

6) K. Koyama, Y. Hashimoto, K. Suzuki and H. Matsuo: J. Jpn. Soc. Powder Powder Metallurg. 36 (1989) 926-932.

7) S. Omori and Y. Hashimoto: J. Jpn. Soc. Powder Powder Metallurg. 20 (1973) 80-86.

8) S. Omori, Y. Hashimoto and K. Koyama: J. Japan Inst. Metals 45 (1981) 1107-1111.

9) S. Omori, Y. Hashimoto and K. Koyama: Koon Gakkaishi 7 (1981) 204-208.

10) S. Omori, Y. Hashimoto and K. Koyama: J. Japan Inst. Metals 46 (1982) 760-763.

11) K. Koyama, M. Morishita and G. Zhang: J. Jpn. Soc. Powder Metallurg. 53 (2006) 419-429.

12) M. Chandra and Q. Xu: J. Power Sources 156 (2006) 190-194.

13) M. Chandra and Q. Xu: J. Power Sources 168 (2007) 135-142.

14) A. Nozaki, S. Kittima, Y. Tanihara, Y. Kuwahara, T. Ohmichi, T. Kamegawa, K. Mori and H. Yamashita: Mater. Trans. 56 (2015) 485489.

15) A. Nozaki, Y. Tanihara, Y. Kuwahara, T. Ohmichi, K. Mori, T. Nagase, H.Y. Yasuda and H. Yamashita: ChemPhysChem 17 (2016) 412-417.

16) A. Nozaki, C. Ueda, R. Fujiwara, A. Yamashita, H. Yamamoto and M. Morishita: Mater. Trans. 60 (2019) 845-848.

17) A. Nozaki, C. Ueda, R. Kameo and M. Morishita: ISIJ Int., in submission.

18) A. Nozaki, R. Fujiwara, C. Ueda, A. Yamashita, H. Yamamoto and M. Morishita: Mater. Trans. 60 (2019) 1964-1967.

19) L. Kaufmann and H. Bernstein: Computer Calculation of Alloy Phase Diagram, (Academic Press, New York, 1970) p. 5.

20) P.K. Liao and K.E. Spear: Bull. Alloy Phase Diagram 9 (1988) 452457.

21) H.X. Li, H. Li, J. Zhang, W.L. Dai and M.H. Qiao: J. Catal. 246 (2007) 301-307.

22) S.J. Chiang, B.J. Liaw and Y.Z. Chen: Appl. Catal. A 319 (2007) 144152.

23) M.P. Pileni: J. Phys. Chem. 97 (1993) 6961-6973. 
24) M.J. Schwuger, K. Stickdorn and R. Schomacker: Chem. Rev. 95 (1995) 849-864.

25) H. Li, J. Liu, S. Xie, M. Qiao, W. Dai and H. Li: J. Catal. 259 (2008) 104-110.

26) H. Gamsjäger, J. Bigajski, T. Gajda, R.J. Lemire and W. Preis: Chemical Thermodynamics of Nickel, ed. by Nuclear Energy Agency, Organization for Economic Co-operation and Development (OECD), Vol. 6, (Chemical Thermodynamics of Nickel, North Holland Elsevier Science Publisher B.V., Amsterdam, The Netherlands, 2005) p. 44.

27) P. Atkins and J. De Paula: Atkins'Physical Chemistry, translated into Japanese by M. Nakano, T. Ueda, M. Okumura and Y. Kitagawa, 10th ed., (Tokyo-Kagaku Dojin, Co. Ltd., Tokyo, 2017) pp. A20-A21.

28) T.B. Reed: Free Energy of Formation of Binary Compounds, (MIT
Press, Cambridge, MA, 1971)

29) G. Zhang, M. Morishita, M. Inada and K. Koyama: Mater. Trans., JIM 41 (2000) 1593-1598.

30) M. Morishita, Y. Kinoshita, H. Houshiyama, A. Nozaki and H. Yamamoto: J. Chem. Thermodyn. 114 (2017) 30-43.

31) M. Morishita, Y. Kinoshita, A. Nozaki and H. Yamamoto: Appl. Geochem. 98 (2018) 310-320.

32) M.E. Ragoussi and S. Brassinnes: Radiochim. Acta 103 (2015) 679685.

33) D.D. Wagman, W.H. Evans, V.B. Parker, R.H. Schumm, I. Halow, S.M. Bailey, K.L. Churney and R.L. Nuttall: J. Phys. Chem. Ref. Data 11(2) (1982) 2-123. 